\title{
RESEARCH PAPER \\ Effect of culture medium and incubation on the characteristics of micropropagated agave plants
}

\author{
José R. Enríquez-del Valle, Karla H. Antonio-Luis, Gerardo Rodríguez- \\ Ortiz, and Gisela V. Campos-Ángeles \\ División de Estudios de Posgrado e Investigación, Instituto Tecnológico del Valle de Oaxaca. Nazareno \\ Xoxocotlán. C.P. 71230. Oaxaca, Mexico.
}

\begin{abstract}
J.R.Enríquez-del Valle, K.H.Antonio-Luis, G. Rodríguez-Ortiz, and G.V.Campos-Ángeles. 2016. Effect of culture medium and incubation on the characteristics of micropropagated agave plants. Cien. Inv. Agr. 43(2):263-272. Agave potatorum Zucc adventitious shoots were obtained in vitro from stem tissues and rooted in different solid media, $\mathrm{pH} 5.8$, containing the following: 1) different concentrations (50, 75, and 100\%) of MS (Murashige and Skoog) mineral salts and 2) different quantities of indole-3-butyric acid (IBA) $\left(0,0.5,1 \mathrm{mg} \mathrm{L}^{-1}\right)$. The shoots in each medium were separated into two groups and incubated for 84 days under different environments, including a laboratory or greenhouse. The experimental design was completely randomized with a $3 \times 3 \times 2$ factorial arrangement. Adventitious roots emerged after 10 to 14 days of incubation, depending on the condition of incubation. In both laboratory and greenhouse settings, after 28 days of incubation, 66.6 and $93.6 \%$ of shoots subjected to treatment medium with $75 \%$ inorganic salts, $0.5 \mathrm{mg} \mathrm{L}^{-1} \mathrm{IBA}$ and medium with $50 \%$ inorganic salts, $1 \mathrm{mg} \mathrm{L}^{-1} \mathrm{IBA}$, respectively, had formed roots. On day 40 , all shoots had roots. After the 84-day rooting stage, the plants grown from the shoots in the medium with $1 \mathrm{mg} \mathrm{L}^{-1}$ IBA were larger in terms of leaf width, stem diameter, and largest leaf base cross-section area, but similar in the number of roots relative to the plants obtained in the media without IBA. Plant size increased with increasing mineral salt concentrations in the medium. Micropropagated plants obtained from the cultures incubated in a greenhouse and laboratory had an 8.9 and $5.4 \mathrm{~cm}$ leaf length, 1.8 and $0.8 \mathrm{~cm}^{3}$ leaf volume, 1.8 and $0.5 \mathrm{~cm}^{3}$ stem diameter, and 6.6 and 5.2 roots, respectively.
\end{abstract}

Key words: fluorescent lighting, incubation environment, indole butyric acid, mineral salts, solar radiation.

\section{Introduction}

In Mexico, species of agave have many uses. The whole plant is used for living fences. The fiber is raw material for manufacturing useful articles. Because agave produce sugars, the

Received August 22, 2015. Accepted March 24, 2016. Corresponding author: grodriguez.itvo@yahoo.com juice is used to produce fermented and distilled beverages (Bautista-Justo et al., 2001). Some species are now being assessed as raw material for the production of biofuels (Escamilla-Treviño, 2012). Agave potatorum Zucc is a wild-type species that is minimally cultivated. This plant grows in semi-arid climates, hilly terrain and poor rocky soils. Agave is very important in 
the towns of the Sierra Sur and Mixtec regions of Oaxaca, Mexico, where it is used mostly to produce "mescal".

The populations of $A$. potatorum Zucc have diminished because they have been exploited intensively for at least four decades with no planning or management to meet the increased demand for mescal (Aguirre-Dugua and Eguiarte, 2013). Mescal producers must walk increasingly greater distances to find these plants. For these reasons, implementing actions for agave conservation (Pérez et al., 2012) is necessary to ensure the supply of raw material.

Enríquez-del Valle (2008) reported that wild agaves such as "tobalá" (A. potatorum Zucc), "jabalí" (A. convallis Trel.), "chato" (A. seemaniana Jacobi) and "ancho" (A. cupreata Trel.) do not produce shoots through rhizomes. Although undocumented, since the 1990s, farmers in the southern mountains of Oaxaca have propagated this species by seed and have established plantations. Because the number of established plants does not compensate the deterioration of this resource, we proposed using the technique of plant tissue culture to propagate $A$. potatorum Zucc (Domínguez et al., 2008) as a complement to conventional methods.

Asexual in vitro propagation of $A$. potatorum Zucc is an important way to produce many plants and establish plantations in a short time to supply the growing demand; however, the characteristics of in vitro environment affect somatic cell processes, such as cell division and morphogenesis in the formation of shoots and roots as well as plant characteristics. The technique can be used for the rescue or conservation of threatened species as well as for large-scale multiplication of superior genotypes, obtaining clonal populations from selected plants. Micropropagation has been used to produce $A$. fourcroydes Lem. (Madrigal et al., 1990), A. cocui Trelease (González et al., 2012), A. karwinskii Zucc. and A. potatorum (Domínguez et al., 2008).
Plant propagation through tissue culture is a clonal propagation system in which the plants obtained retain all of the genotypic characteristics of the selected initial material. The entire process is conducted in controlled laboratory environments and, when there is a propagation methodology appropriate to the species of interest and the propagules have been established and adapted to in vitro conditions, micropropagation can produce a higher number of plants. Moreover, the plants obtained are healthier than those grown in a nursery (Domínguez et al., 2008; Enríquez-del Valle, 2008).

The micropropagation process includes the following several stages: 1) selection and preparation of the mother plant; 2) surface disinfection of the tissues or organs to be used as explants and/or surface disinfection of seeds; 3 ) in vitro establishment of the selected material; 4) propagule multiplication; 5) rooting; and 6) transfer of the in vitro plants to pots with substrate for acclimatization (Debergh and Read, 1991). Transferring the shoots from step 3 to 4 requires designing a suitable culture medium that will induce shoots, although at this stage the stem and leaves also grow. The plant characteristics at the end of this stage influence their capacity to adapt and grow ex vitro. The culture medium must provide mineral and organic nutrients; the balance of growth regulators should decrease cytokinins and increase exogenous auxin. Agave sp. shoots were rooted in a growth regulator-free MS medium (Zhang et al., 2013). The combination of auxins and reduced MS salt concentration in the culture media have a promontory effect on shoot rooting of Agapanthus praecox (Baskaran and Van-Staden, 2013), Bambusa balcooa Roxb. (Negi and Saxena, 2011) and A. angustifolia Haw. (Enríquez-del Valle et al., 2005).

For the in vitro propagation of banana plants (Musa sp.), some references show that at the shoot rooting stage incubation is possible in conditions of diminished solar radiation (50 to $69 \%$ ), a stage called pre-acclimatization. When 
the plants micropropagated in these conditions were established in containers with substrate in a greenhouse, they underwent less stress than in vitro plants incubated under fluorescent lighting in the laboratory (Scaranari et al., 2009). This study proposes to assess shoot rooting and plant characteristics of $A$. potatorum Zucc propagated in vitro in culture media with different concentrations of mineral salts and indole-3-butyric acid (IBA) and incubated under fluorescent lighting in the laboratory or under diffuse solar radiation in a greenhouse.

\section{Material and methods}

The experiment was conducted in 2014 in the plant tissue culture laboratory and a greenhouse of the Instituto Tecnológico del Valle de Oaxaca, located in Nazareno Xoxocotlán, Oaxaca, México. We used aseptic in vitro cultures of $A$. potatorum Zucc shoots in the stage of propagule multiplication. A solid medium was prepared with mineral MS (Murashige and Skoog) salts (Murashige and Skoog, 1962) that included 100 $\mathrm{mg} \mathrm{L}^{-1}$ myo-inositol, $30 \mathrm{~g} \mathrm{~L}^{-1}$ sucrose, $1 \mathrm{mg} \mathrm{L}^{-1}$ $\mathrm{N}^{6}$ - benzylaminopurine and $0.4 \mathrm{mg} \mathrm{L}^{-1}$ thiamine$\mathrm{HCl}$. The $\mathrm{pH}$ was adjusted to 5.8 before adding $5.5 \mathrm{~g} \mathrm{~L}^{-1}$ of agar. The cultures were incubated for 50 days under white fluorescent light, $37 \mu \mathrm{mol}$ $\mathrm{m}^{-2} \mathrm{~s}^{-1}$ in photoperiods of $16 \mathrm{~h}$ and $8 \mathrm{~h}$ darkness, at a temperature between 18 and $28{ }^{\circ} \mathrm{C}$, dark light $^{-1}$. At the end of this period in each explant, clusters of 6 to 12 shoots of heterogeneous size had formed on a callus base.

Under aseptic conditions in a horizontal laminar flow cabinet (Forma Scientific brand, model 1839, Houston, TX, USA), the clusters of shoots were removed from the culture medium and placed in a sterile glass Petri dish to select the shoots whose longest leaf measured 3.5 to $5 \mathrm{~cm}$. With sterile forceps and a scalpel, the selected shoots were separated individually, and three shoots were placed in each $165 \mathrm{~cm}^{3}$ flask containing 25 $\mathrm{mL}$ of solid culture medium to induce rooting.
Nine different media were prepared as follows: 1) similar concentrations of thiamine-HCL $(0.4$ $\left.\mathrm{mg} \mathrm{L}^{-1}\right)$, myo-inositol $\left(50 \mathrm{mg} \mathrm{L}^{-1}\right)$, sucrose (30 $\mathrm{g}$ $\left.\left.\mathrm{L}^{-1}\right), 2\right) \mathrm{MS}$ inorganic salts in different concentrations (50, 75 and 100\%), 3) indole-3-butyric acid (IBA) in different concentrations (no IBA, 0.5 or $1 \mathrm{mg} \mathrm{L}^{-1}$ ). The $\mathrm{pH}$ was adjusted to 5.8 with $\mathrm{HCL}$ or $1 \mathrm{~N} \mathrm{NaOH}$ before adding $5.5 \mathrm{~g} \mathrm{~L}^{-1}$ agar, which was dissolved with heat and shaking. Each flask with $25 \mathrm{~mL}$ of a medium was covered with a polypropylene cap and sterilized in an autoclave (INOLAB Specialists, Mexico city, Mexico) for 17 minutes at $1.2 \mathrm{~kg} \mathrm{~cm}^{-2}$ pressure and $120{ }^{\circ} \mathrm{C}$.

After the shoots were established, the flask was sealed with the polypropylene cap and polyethylene adhesive. Each culture medium was distributed in 20 flasks containing three shoots each. To study the effect of environment, 30 shoots (10 flasks) in each medium were incubated in a laboratory where they were exposed to white fluorescent lighting, $37 \mu \mathrm{mol} \mathrm{m}{ }^{-2} \mathrm{~s}^{-1}$ in photoperiods of $16 \mathrm{~h}$ and $8 \mathrm{~h}$ of darkness and at a temperature between 20 to $28^{\circ} \mathrm{C}$. The other 30 shoots were incubated in a nursery inside a greenhouse $1 \mathrm{~m}$ wide, 1.5 $\mathrm{m}$ long and $1.7 \mathrm{~m}$ high with translucent white polyethylene covering, where solar radiation at noon was $400 \mu \mathrm{mol} \mathrm{m}^{-2} \mathrm{~s}^{-1}$; the photoperiod and temperatures were those that occurred naturally inside the structure. The experimental design was completely randomized with a $3 \times 3 \times 2$ factorial arrangement (three concentrations of mineral salts, three IBA concentrations in the culture medium, two incubation conditions) resulting in 18 treatments (Table 1). The experimental unit was one shoot and each treatment contained 30 replications.

The percentage of rooted shoots was calculated after 28 and 40 days of incubation. After 84 days of incubation, eight plants per treatment were collected to determine the following characteristics: number of leaves, length and width of the largest leaf, leaf area, largest leaf base cross-section area, foliar volume, number and volume of roots, stem diameter and total dry weight. The leaf area was 
Table 1. Treatments $\left(\mathrm{T}_{\mathrm{i}}\right)$ applied for shoot rooting of Agave potatorum Zucc.

\begin{tabular}{lcccc}
\hline & & \multicolumn{3}{c}{ Murashige and Skoog Inorganic salts (\%) } \\
\cline { 3 - 5 } Incubation & $\begin{array}{c}\text { Indole-3-butyric acid } \\
\left(\mathrm{mg} \mathrm{L}^{-1}\right)\end{array}$ & 50 & 75 & 100 \\
\hline Laboratory & 0 & $\mathrm{~T}_{1}$ & $\mathrm{~T}_{4}$ & $\mathrm{~T}_{7}$ \\
& 0.5 & $\mathrm{~T}_{2}$ & $\mathrm{~T}_{5}$ & $\mathrm{~T}_{8}$ \\
Greenhouse & 1.0 & $\mathrm{~T}_{3}$ & $\mathrm{~T}_{6}$ & $\mathrm{~T}_{9}$ \\
& 0 & $\mathrm{~T}_{10}$ & $\mathrm{~T}_{13}$ & $\mathrm{~T}_{16}$ \\
& 0.5 & $\mathrm{~T}_{11}$ & $\mathrm{~T}_{14}$ & $\mathrm{~T}_{17}$ \\
& 1.0 & $\mathrm{~T}_{12}$ & $\mathrm{~T}_{15}$ & $\mathrm{~T}_{18}$ \\
\hline
\end{tabular}

determined using Image $₫$ software. The largest leaf base cross-section area was determined by placing a $0.5 \mathrm{~mm}$ thick section on a glass slide marked with a millimetric scale. The leaf volume was calculated by separating the leaves from the stem and submerging them in a known volume of water in a $5 \mathrm{~mL}$ test tube. The data were subjected to an analysis of variance, and the means were compared with Tukey test $(\alpha=0.05)$ in r Statistic ${ }^{\circledR}$ software.

\section{Results and discussion}

Micropropagated plants must undergo a process of acclimatization to allow gradual adaptation to an ex vitro environment. In the protocols of in vitro propagation, the propagules are commonly incubated at all stages under laboratory conditions. The shoots cultured in vitro in the rooting stage are subjected to low light intensity, and the obtained plants are transferred to a greenhouse and subjected to greater light intensity. The drastic change from in vitro to ex vitro can cause plant stress or death. During in vitro rooting of Agapanthus praecox (Baskaran and Van-Staden, 2013) and Musa (Aragon et al., 2005), the shoots were incubated at $25 \pm 2{ }^{\circ} \mathrm{C}$ under white fluorescent lighting with a photon flux density of $40 \mu \mathrm{mol}$

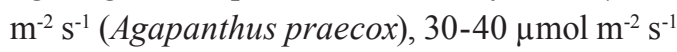
(Musa). The micropropagated plants were transferred to substrate and growth room and subjected to solar radiation, $950 \pm 50 \mu \mathrm{mol} \mathrm{m} \mathrm{m}^{-2} \mathrm{~s}^{-1}$ at noon (A. praecox), $2000 \mu \mathrm{mol} \mathrm{m}^{-2} \mathrm{~s}^{-1}$ (Musa). MiguelLuna et al. (2013) incubated in vitro cultures of
A. americana shoots for a 60 -day rooting stage in two environments, either a laboratory under white fluorescent lighting $\left(37 \mu \mathrm{mol} \mathrm{m}^{-2} \mathrm{~s}^{-1}\right)$ or a greenhouse under diffuse solar radiation (300 $\mu \mathrm{mol} \mathrm{m} \mathrm{m}^{-2} \mathrm{~s}^{-1}$. At the end of this stage, the plants obtained from the cultures incubated under greenhouse conditions had a higher dry weight and thicker leaves than the plants obtained from the cultures incubated in the laboratory. The exposure of in vitro cultures to solar radiation can affect the morphology of the leaves and stem. Fondom et al. (2009) reported that the exposure of $A$. striata Zucc. plants to solar radiation in the field was related to the deposition of wax and anthocyanin in the leaves.

We hypothesized that conditions of an in vitro environment affect morphological characteristics of micropropagated plants and their capacity to adapt to an ex vitro environment. In our study, A. potatorum Zucc shoots were established in different culture media that varied in the concentration of MS inorganic salts and auxin IBA. Half of the plants were incubated in the laboratory and the other half in a greenhouse, and their root formation was assessed. The first adventitious roots emerged between 10 and 14 days under different growing conditions. After 28 days of incubation, 66.6 to $93.6 \%$ of the shoots had formed roots (Table 2), including the shoots in culture medium without auxin. After 40 days, all of the shoots had rooted.

After 84 days of incubation in the laboratory, the shoots in the media with $100 \%$ MS salts and 0.5 
Table 2. Rooted shoots of Agave potatorum Zucc in response to variations in culture medium and incubation, evaluated after 28 and 40 days of incubation.

\begin{tabular}{cccc}
\hline & & \multicolumn{2}{c}{ Rooted shoots (\%) } \\
\cline { 3 - 4 } Treatment $\left(\mathrm{T}_{\mathrm{i}}\right)$ & Days after that root emerged & 28 days & 40 days \\
\hline T1 & 12 & 86.5 & 100 \\
T2 & 10 & 78.7 & 100 \\
T3 & 12 & 93.6 & 100 \\
T4 & 13 & 79.3 & 100 \\
T5 & 10 & 66.6 & 100 \\
T6 & 14 & 78.2 & 100 \\
T7 & 12 & 91.3 & 100 \\
T8 & 12 & 85.0 & 100 \\
T9 & 14 & 72.7 & 100 \\
T10 & 12 & 86.5 & 100 \\
T11 & 10 & 78.7 & 100 \\
T12 & 12 & 93.6 & 100 \\
T13 & 13 & 79.3 & 100 \\
T14 & 10 & 66.6 & 100 \\
T15 & 14 & 78.2 & 100 \\
T16 & 12 & 91.3 & 100 \\
T17 & 12 & 85.0 & 100 \\
T18 & 14 & 72.7 & 100 \\
\hline
\end{tabular}

mg L ${ }^{-1}$ IBA and the shoots in media with $50 \% \mathrm{MS}$ salts and $1 \mathrm{mg} \mathrm{L}^{-1}$ IBA had 3.1 to 7.5 adventitious roots (Table 3). Enríquez-del Valle et al. (2005) reported that $A$. angustifolia Haw shoots grew in vitro in culture media with MS mineral salts ranging from 50 to $100 \%$ strength and 0 to $1 \mathrm{mg}$ $\mathrm{L}^{-1}$ indole-3-butyric acid. Under both conditions, $100 \%$ of the shoots formed adventitious roots, but the number of roots per shoot increased with increasing concentrations of IBA, up to $1 \mathrm{mg} \mathrm{L}^{-1}$, and decreasing concentration of inorganic salts, up to $50 \%$, in the culture media.

Different studies have reported that shoots established in media without auxin formed adventitious roots, Philodendron spp. (Blanco and Valverde, 2004) and Paulownia elongata S.Y. Hu (Castellanos et al., 2006). In the A. potatorum Zucc shoots, endogenous synthesis of this substance may have occurred because the auxins are growth regulators that induce organogenetic formation of adventitious roots. The auxin indolyl-3-acetic acid, IAA, is produced endogenously in the leaves and exported to the stem where it induces root formation (Garrido et al., 2002).

After 84 days under the different culture conditions, the analysis of variance showed that the concentrations of inorganic salts had significant effects $(P \leq 0.05)$ on the width of the largest leaf and on the leaf volume, and highly significant effects $(\mathrm{P} \leq 0.01)$ on the number of leaves, length of the largest leaf, stem diameter and total dry weight.

Indole-3-butyric acid levels caused significant differences $(\mathrm{P} \leq 0.05)$ in stem diameter and cross sectional area of the largest leaf and highly significant differences $(\mathrm{P} \leq 0.01)$ in leaf width. Incubation environments had significant effects $(\mathrm{P} \leq 0.05)$ on leaf length and highly significant effects $(\mathrm{P} \leq 0.01)$ on stem diameter and leaf volume. The interaction between the factors inorganic salt concentration and IBA concentration had a significant effect $(P \leq 0.05)$ on leaf area, and a highly significant $(\mathrm{P} \leq 0.01)$ effect on leaf number. The interaction of salt concentration and incubation environment 
Table 3. Characteristics of Agave potatorum Zucc. obtained under different conditions of in vitro culture at the end of the rooting stage.

\begin{tabular}{|c|c|c|c|c|c|c|c|c|c|}
\hline $\begin{array}{l}\text { Treatment } \\
\text { IE-IBA-S }\end{array}$ & NL & $\begin{array}{l}\mathrm{LL} \\
(\mathrm{cm})\end{array}$ & $\begin{array}{l}\text { WL } \\
(\mathrm{cm})\end{array}$ & $\begin{array}{l}\mathrm{SD} \\
(\mathrm{cm})\end{array}$ & NR & $\begin{array}{c}\mathrm{LV} \\
\left(\mathrm{cm}^{3}\right)\end{array}$ & $\begin{array}{l}\mathrm{RV} \\
\left(\mathrm{cm}^{3}\right)\end{array}$ & $\begin{array}{c}\mathrm{LA} \\
\left(\mathrm{cm}^{2}\right)\end{array}$ & $\begin{array}{c}\text { TDW } \\
(\mathrm{g})\end{array}$ \\
\hline L- $0.0-50$ & $4.0 \mathrm{a}$ & 5.2 ef & $0.63 \mathrm{a}$ & $0.37 \mathrm{f}$ & $4.8 \mathrm{a}$ & $0.23 \mathrm{e}$ & $0.11 \mathrm{a}$ & $6.4 \mathrm{a}$ & $0.4 \mathrm{a}$ \\
\hline L- $0.5-50$ & $5.0 \mathrm{a}$ & $6.2 \mathrm{cf}$ & $0.67 \mathrm{a}$ & $0.45 \mathrm{f}$ & $5.3 \mathrm{a}$ & $0.90 \mathrm{~b}-\mathrm{e}$ & $0.16 \mathrm{a}$ & $6.3 \mathrm{a}$ & $0.5 \mathrm{a}$ \\
\hline L-1.0-50 & $5.1 \mathrm{a}$ & $5.8 \mathrm{~d}-\mathrm{f}$ & $0.70 \mathrm{a}$ & $0.64 \mathrm{ef}$ & $7.5 \mathrm{a}$ & $0.50 \mathrm{de}$ & $0.16 \mathrm{a}$ & $6.7 \mathrm{a}$ & $0.4 \mathrm{a}$ \\
\hline L-0.0-75 & $6.2 \mathrm{a}$ & $6.0 \mathrm{c}-\mathrm{f}$ & $0.63 \mathrm{a}$ & $0.48 \mathrm{f}$ & $4.9 \mathrm{a}$ & $0.98 \mathrm{~b}-\mathrm{e}$ & $0.12 \mathrm{a}$ & $6.8 \mathrm{a}$ & $0.1 \mathrm{a}$ \\
\hline L-0.5-75 & $4.2 \mathrm{a}$ & $4.5 \mathrm{f}$ & $0.71 \mathrm{a}$ & $0.45 \mathrm{f}$ & $5.1 \mathrm{a}$ & $0.62 \mathrm{c}-\mathrm{e}$ & $0.10 \mathrm{a}$ & $6.3 \mathrm{a}$ & $0.3 \mathrm{a}$ \\
\hline L-1.0-75 & $6.0 \mathrm{a}$ & 5.1 ef & $0.88 \mathrm{a}$ & $0.61 \mathrm{ef}$ & $6.8 \mathrm{a}$ & $0.85 \mathrm{~b}-\mathrm{e}$ & $0.15 \mathrm{a}$ & $6.6 \mathrm{a}$ & $0.5 \mathrm{a}$ \\
\hline L-0.0-100 & $5.2 \mathrm{a}$ & $5.6 \mathrm{~d}-\mathrm{f}$ & $0.67 \mathrm{a}$ & $0.34 \mathrm{f}$ & $4.5 \mathrm{a}$ & $0.91 \mathrm{~b}-\mathrm{e}$ & $0.12 \mathrm{a}$ & $6.2 \mathrm{a}$ & $0.3 \mathrm{a}$ \\
\hline L-0.5-100 & $6.2 \mathrm{a}$ & $5.4 \mathrm{~d}-\mathrm{f}$ & $0.83 \mathrm{a}$ & $0.64 \mathrm{ef}$ & $3.1 \mathrm{a}$ & 0.93 b-e & $0.11 \mathrm{a}$ & $6.5 \mathrm{a}$ & $0.1 \mathrm{a}$ \\
\hline L-1.0-100 & $6.3 \mathrm{a}$ & $5.6 \mathrm{~d}-\mathrm{f}$ & $0.88 \mathrm{a}$ & $0.58 \mathrm{ef}$ & $5.1 \mathrm{a}$ & $1.10 \mathrm{~b}-\mathrm{e}$ & $0.12 \mathrm{a}$ & $8.4 \mathrm{a}$ & $0.4 \mathrm{a}$ \\
\hline G-0.0-50 & $4.7 \mathrm{a}$ & $7.3 \mathrm{~b}-\mathrm{f}$ & $0.60 \mathrm{a}$ & $1.08 \mathrm{~d}-\mathrm{f}$ & $5.6 \mathrm{a}$ & $1.42 \mathrm{a}-\mathrm{e}$ & $0.12 \mathrm{a}$ & $6.2 \mathrm{a}$ & $0.2 \mathrm{a}$ \\
\hline G-0.5-50 & $5.8 \mathrm{a}$ & $8.8 \mathrm{a}-\mathrm{d}$ & $0.73 \mathrm{a}$ & $1.56 \mathrm{~b}-\mathrm{e}$ & $4.5 \mathrm{a}$ & $1.93 \mathrm{a}-\mathrm{c}$ & $0.15 \mathrm{a}$ & $6.2 \mathrm{a}$ & $0.3 \mathrm{a}$ \\
\hline G-1.0-50 & $4.7 \mathrm{a}$ & 7.4 b-f & $0.68 \mathrm{a}$ & $1.31 \mathrm{c}-\mathrm{f}$ & $6.0 \mathrm{a}$ & $2.05 \mathrm{ab}$ & $0.16 \mathrm{a}$ & $7.0 \mathrm{a}$ & $0.4 \mathrm{a}$ \\
\hline G-0.0-75 & $5.3 \mathrm{a}$ & $7.9 \mathrm{a}-\mathrm{f}$ & $0.71 \mathrm{a}$ & $1.70 \mathrm{~b}-\mathrm{d}$ & $5.9 \mathrm{a}$ & $1.74 \mathrm{a}-\mathrm{d}$ & $0.15 \mathrm{a}$ & $8.4 \mathrm{a}$ & $0.3 \mathrm{a}$ \\
\hline G-0.5-75 & $5.1 \mathrm{a}$ & $8.2 \mathrm{a}-\mathrm{e}$ & $0.67 \mathrm{a}$ & $1.76 \mathrm{a}-\mathrm{d}$ & $5.3 \mathrm{a}$ & $1.47 \mathrm{a}-\mathrm{e}$ & $0.13 \mathrm{a}$ & $6.1 \mathrm{a}$ & $0.2 \mathrm{a}$ \\
\hline G-1.0-75 & $5.3 \mathrm{a}$ & $9.4 \mathrm{a}-\mathrm{c}$ & $0.71 \mathrm{a}$ & $2.07 \mathrm{a}-\mathrm{c}$ & $4.8 \mathrm{a}$ & $1.60 \mathrm{a}-\mathrm{e}$ & $0.13 \mathrm{a}$ & $6.8 \mathrm{a}$ & $0.3 \mathrm{a}$ \\
\hline G-0.0-100 & $5.1 \mathrm{a}$ & 8.9 a-d & $0.72 \mathrm{a}$ & $2.32 \mathrm{a}-\mathrm{c}$ & $6.0 \mathrm{a}$ & $1.55 \mathrm{a}-\mathrm{e}$ & $0.12 \mathrm{a}$ & $6.5 \mathrm{a}$ & $0.4 \mathrm{a}$ \\
\hline G-0.5-100 & $6.5 \mathrm{a}$ & $11.1 \mathrm{a}$ & $0.75 \mathrm{a}$ & $2.32 \mathrm{ab}$ & $5.8 \mathrm{a}$ & $2.15 \mathrm{ab}$ & $0.13 \mathrm{a}$ & $7.6 \mathrm{a}$ & $0.4 \mathrm{a}$ \\
\hline G-1.0-100 & $6.3 \mathrm{a}$ & $10.8 \mathrm{ab}$ & $0.75 \mathrm{a}$ & $2.69 \mathrm{a}$ & $5.6 \mathrm{a}$ & $2.68 \mathrm{a}$ & $0.12 \mathrm{a}$ & $6.3 \mathrm{a}$ & $0.5 \mathrm{a}$ \\
\hline
\end{tabular}

Different letters within a column indicate significant differences (Tukey, $\mathrm{P} \leq 0.05$ ). Values represent means $(\mathrm{n}=8)$. IE: incubation environment ( $\mathrm{L}=$ laboratory; $\mathrm{G}=$ greenhouse greenhouse), IBA: indole 3-butyric acid, $\mathrm{S}$ : inorganic salts. ${ }^{2} \mathrm{NL}$ : number of leaves, LL: length of the largest leaf, WL: width of the largest leaf, SD: stem diameter, NR: number of roots, LV: leaf volume, RV: root volume, LA: leaf area, TDW: total dry weight.

had highly significant effects $(\mathrm{P} \leq 0.01)$ on leaf length and stem diameter. The concentration of inorganic salts and IBA in the culture medium had no effect on adventitious root formation in $A$. potatorum shoots, nor did the physical environment of incubation. These factors, however, did influence other morphological characteristics of the plants.

The findings of this study confirm that varying the components of the culture medium combined with conditions of incubation affect the characteristics of A. potatorum plants obtained at the end of the micropropagation process. The shoots established in the media without IBA and the shoots in the media with $1 \mathrm{mg} \mathrm{L}^{-1}$ IBA produced plants whose largest leaves were 0.6 and $0.77 \mathrm{~cm}$ wide, stem diameter was 1.0 and $1.3 \mathrm{~cm}$, and leaf cross section area was 1.2 and $1.4 \mathrm{~mm}^{2}$, respectively. These quantities are significantly different (Tukey, $\mathrm{P} \leq$ 0.05) (Table 4).
Higher concentrations of inorganic salts in the culture medium produced larger plants. Comparing the shoots established in the media with $50 \%$ inorganic salts and those established in the media with $100 \%$ inorganic salts, the plants grew 4.9 and 5.9 leaves, which were 6.8 and $7.9 \mathrm{~cm}$ long, 0.67 and $0.77 \mathrm{~cm}$ wide, respectively, while the stem diameters were 0.9 and $1.5 \mathrm{~cm}$ and the leaf volumes were 0.8 and $1.6 \mathrm{~cm}^{3}$, respectively. These values are significantly different (Tukey, $\mathrm{P} \leq 0.05)$.

All of the A. potatorum shoots formed adventitious roots, even in the culture media with no auxins. The shoots established in the culture media without auxins and the shoots in the media with 0.5 or $1 \mathrm{mg} \mathrm{L}^{-1}$ IBA formed 5.2, 4.8 and 5.9 roots, which had volumes of $0.14,0.13$ and 0.12 $\mathrm{cm}^{3}$, respectively. These differences, however, were not significant (Tukey, $\mathrm{P} \leq 0.05$ ). Addition- 
Table 4. Characteristics of Agave potatorum Zucc. plants according to principal factor levels.

\begin{tabular}{|c|c|c|c|c|c|c|c|c|c|c|}
\hline \multirow[b]{2}{*}{ Factors $^{1}$} & \multicolumn{10}{|c|}{ Plant characteristics $^{2}$} \\
\hline & NL & $\begin{array}{l}\mathrm{LL} \\
(\mathrm{cm})\end{array}$ & $\begin{array}{l}\text { WL } \\
(\mathrm{cm})\end{array}$ & NR & $\begin{array}{l}\text { SD } \\
(\mathrm{cm})\end{array}$ & $\begin{array}{c}\mathrm{LV} \\
\left(\mathrm{cm}^{3}\right)\end{array}$ & $\begin{array}{c}\mathrm{RV} \\
\left(\mathrm{cm}^{3}\right)\end{array}$ & $\begin{array}{l}\text { TDW } \\
(\mathrm{g})\end{array}$ & $\begin{array}{c}\mathrm{CAL} \\
\left(\mathrm{mm}^{2}\right)\end{array}$ & $\begin{array}{c}\mathrm{LA} \\
\left(\mathrm{cm}^{2}\right)\end{array}$ \\
\hline \multicolumn{11}{|l|}{$\begin{array}{l}\text { IBA dose } \\
\left(\mathrm{mg} \mathrm{L}^{-1}\right)\end{array}$} \\
\hline 0 & $5.1 \mathrm{a}$ & $6.8 \mathrm{a}$ & $0.6 \mathrm{~b}$ & $5.3 \mathrm{a}$ & $1.0 \mathrm{~b}$ & $1.1 \mathrm{a}$ & $0.12 \mathrm{a}$ & $0.28 \mathrm{a}$ & $1.2 \mathrm{~b}$ & $6.7 \mathrm{a}$ \\
\hline 0.5 & $5.3 \mathrm{a}$ & $7.3 \mathrm{a}$ & $0.73 \mathrm{ab}$ & $4.9 \mathrm{a}$ & $1.2 \mathrm{ab}$ & $1.3 \mathrm{a}$ & $0.13 \mathrm{a}$ & $0.30 \mathrm{a}$ & $1.4 \mathrm{a}$ & $6.5 \mathrm{a}$ \\
\hline 1 & $5.6 \mathrm{a}$ & $7.4 \mathrm{a}$ & $0.77 \mathrm{a}$ & $5.9 \mathrm{a}$ & $1.3 \mathrm{a}$ & $1.5 \mathrm{a}$ & $0.14 \mathrm{a}$ & $0.41 \mathrm{a}$ & $1.4 \mathrm{a}$ & $7.0 \mathrm{a}$ \\
\hline \multicolumn{11}{|l|}{ Salts MS (\%) } \\
\hline 50 & $4.9 \mathrm{~b}$ & $6.8 \mathrm{~b}$ & $0.67 \mathrm{~b}$ & $5.6 \mathrm{a}$ & $0.9 \mathrm{c}$ & $0.8 \mathrm{~b}$ & $0.14 \mathrm{a}$ & $0.36 \mathrm{a}$ & $1.3 \mathrm{a}$ & $6.5 \mathrm{a}$ \\
\hline 75 & $5.4 \mathrm{ab}$ & $6.9 \mathrm{~b}$ & $0.72 \mathrm{ab}$ & $5.5 \mathrm{a}$ & $1.2 \mathrm{~b}$ & $1.2 \mathrm{ab}$ & $0.13 \mathrm{a}$ & $0.28 \mathrm{a}$ & $1.4 \mathrm{a}$ & $6.8 \mathrm{a}$ \\
\hline 100 & $5.9 \mathrm{a}$ & $7.9 \mathrm{a}$ & $0.77 \mathrm{a}$ & $5.0 \mathrm{a}$ & $1.5 \mathrm{a}$ & $1.6 \mathrm{a}$ & $0.12 \mathrm{a}$ & $0.35 \mathrm{a}$ & $1.3 \mathrm{a}$ & $6.9 \mathrm{a}$ \\
\hline \multicolumn{11}{|l|}{ IE } \\
\hline $\mathrm{L}$ & $5.4 \mathrm{a}$ & $5.4 \mathrm{~b}$ & $0.73 \mathrm{a}$ & $5.2 \mathrm{a}$ & $0.5 \mathrm{~b}$ & $0.8 \mathrm{~b}$ & $0.12 \mathrm{a}$ & $0.33 \mathrm{a}$ & $1.3 \mathrm{a}$ & $6.7 \mathrm{a}$ \\
\hline G & $5.5 \mathrm{a}$ & $8.9 \mathrm{a}$ & $0.70 \mathrm{a}$ & $6.6 \mathrm{a}$ & $1.8 \mathrm{a}$ & $1.8 \mathrm{a}$ & $0.13 \mathrm{a}$ & $0.33 \mathrm{a}$ & $1.3 \mathrm{a}$ & $6.8 \mathrm{a}$ \\
\hline
\end{tabular}

Different letters within a column by factor indicate significant differences (Tukey, $\mathrm{P} \leq 0.05$ ). IBA= indole-3-butyric acid; $\mathrm{IE}=$ incubation environment $(\mathrm{L}=\mathrm{lab} ; \mathrm{G}=$ greenhouse); $\mathrm{NL}=$ number of leaves; $\mathrm{LL}=$ length of the largest leaf; $\mathrm{WL}=\mathrm{width}$ of the largest leaf; $\mathrm{NR}=$ number of roots; $\mathrm{SD}=$ stem diameter; $\mathrm{LV}=$ leaf volume; $\mathrm{RV}=$ root volume; $\mathrm{TDW}=$ total dry weight; $\mathrm{CAL}=$ cross-sectional area of the largest leaf; $\mathrm{LA}=$ leaf area.

ally, the concentration of inorganic salts in the culture medium, the incubation environment and the diverse interactions had no effect on root formation (Tables 3 and 4).

The above results differ with those reported by Enríquez-del Valle et al. (2005), who reported that the best shoot rooting response of $A$. angustifolia occurred when they were established in culture media with MS inorganic salts decreased to a $75 \%$ concentration and $1 \mathrm{mg} \mathrm{L}^{-1} \mathrm{IBA}$, relative to shoots established in media with $100 \%$ MS salts without auxins. For in vitro propagation of $A$. grijalvensis B. Ullrich, Sánchez-Urbina et al. (2008) reported that shoots showed the best rooting response when they were grown in culture medium with MS mineral salts at a 50\% concentration and $22.7 \mu \mathrm{M}$ IBA, while Pérez et al. (2012) reported that shoots of A. bracteosa $\mathrm{S}$. Watson ex Engelm., A. cupreata Trel et Berg., $A$. karwinskii, A. ornithobroma Gentry, A. potatorum, A. titanota Gentry, A. nizandensis Cutak., A. peacockii Croucher, A. victoria-reginae T.
Moore and A. chiapensis Jacobi formed roots when they were established in media with $50 \%$ mineral salts without auxins.

Shoots in T17 (media with 100\% inorganic salts, $0.5 \mathrm{mg} \mathrm{L}^{-1}$ IBA, and incubated under a greenhouse) and shoots in T2 (media with $50 \%$ mineral salts, $0.5 \mathrm{mg} \mathrm{L}^{-1} \mathrm{IBA}$ and incubated in laboratory) produced plants of different sizes: leaves of 11.1 and $6.2 \mathrm{~cm}$ long, leaf volume of 2.15 and $0.90 \mathrm{~cm}^{3}$ and stem diameter of 2.32 to $0.45 \mathrm{~cm}$, respectively. In each case, the values were significantly different (Tukey, $\mathrm{P} \leq 0.05$ ) (Table 3).

During the in vitro propagation of 10 species of Agave, Pérez et al. (2012) incubated the cultures under fluorescent lighting at $54 \mu \mathrm{mol} \mathrm{m} \mathrm{m}^{-2} \mathrm{~s}^{-1}$, while in propagating A. cocui, González et al. (2012) incubated cultures under fluorescent lighting at $33.4 \mu \mathrm{mol} \mathrm{m} \mathrm{m}^{-2} \mathrm{~s}^{-1}$. In field conditions, solar radiation reaches a photosynthetic photon flux density, PPFD, of 1500-2000 $\mu \mathrm{mol} \mathrm{m} \mathrm{m}^{-2} \mathrm{~s}^{-1}$, which is 37-59 times the flux density of photons to which 
in vitro cultures were exposed in the laboratory conditions. Subjecting micropropagated plants to such a drastic change is not recommended. Abreu et al. (2007) placed A. fourcroydes plants produced in vitro in a greenhouse where solar radiation decreased to $30 \%$ (558.74 a 686.55 $\mu \mathrm{mol} \mathrm{m} \mathrm{m}^{-2} \mathrm{~s}^{-1}$ ) during their first 14 days of acclimatization; after this period, the plants were then exposed to more intense solar radiation (1303.37 a $1602.04 \mu \mathrm{mol} \mathrm{m}^{-2} \mathrm{~s}^{-1}$ ).

Whether variation in morphological characteristics observed in plants obtained from in vitro cultures incubated in the greenhouse correspond to a pre-acclimatization condition is necessary to determine. In our study, the micropropagated plants exhibited different morphological features according to the physical environment of the incubation from which they were obtained. The shoots incubated under a greenhouse, exposed to $400 \mu \mathrm{mol} \mathrm{m}{ }^{-2} \mathrm{~s}^{-1}$ solar radiation, produced plants with larger stems, more rigid leaves, and pale green pigmentation with a reddish basal area. In contrast, the plants obtained from the cultures incubated in the laboratory, under white fluorescent lighting at $37 \mu \mathrm{mol} \mathrm{m} \mathrm{m}^{-2} \mathrm{~s}^{-1}$, had green pigmentation. The reddish pigmentation of $A$. potatorum plants could be due to anthocyanins in foliar tissues. Fondom et al. (2009) in A. striata stated that the red pigmentation of the leaves is the result of anthocyanins that accumulate in the adaxial and abaxial epidermal layers, which mask the green chlorophyll pigments. In young leaves, anthocyanins are produced in response to light intensity that exceeds the requirements for photosynthesis, making them more susceptible to photoinhibition than mature leaves. Thus, one can infer that anthocyanins have a protective function against harmful levels of light, especially high energy blue wavelengths.
In in vitro cultures of Solanum tuberosum L. incubated in the laboratory under fluorescent lighting at different photosynthetic photon flux densities (PPFD), from 30 up to $120 \mu \mathrm{mol} \mathrm{m} \mathrm{m}^{-2} \mathrm{~s}^{-1}$, leaf area and fresh and dry weights increased as the exposure to PPFD increased up to $90 \mu \mathrm{mol} \mathrm{m}{ }^{-2} \mathrm{~s}^{-1}$ (Kitaya et al., 1995). In some micropropagation schemes of banana (Musa sp.), for the stage of shoot rooting in preparation for transplant to soil, in vitro cultures should be kept in a nursery for one month. This pre-adaptation procedure yielded more vigorous plants with better pigmentation, photosynthetic activity and waxy cuticle. These features enable plants to adapt better when transplanted to pots than plants produced in vitro and incubated entirely in the laboratory (Teixeira et al., 2005).

For the successful establishment of micropropagated plants to ex vitro conditions, control of the acclimatization environment and characteristics of micropropagated plants should be considered (Cui et al., 2000; Pospíšilová et al., 2000). DomínguezTorrejón and Donayre-Gómez (2006) suggest taking the in vitro cultures to a greenhouse to start conditioning because the plants obtained under these conditions suffer relatively less stress when they are transferred from in vitro to in vivo than the plants obtained from cultures incubated in the laboratory.

A. potatorum Zucc. shoots established in the culture medium with $1 \mathrm{mg} \mathrm{L}^{-1}$ IBA produced plants with broader leaves, a larger stem diameter and greater leaf base cross sectional area than the plants grown in the cultures without IBA. Larger plants were obtained in higher concentrations of MS inorganic salts up to $100 \%$ in the culture medium. The plants produced by shoots incubated in a greenhouse environment had a similar number of roots but longer leaves and a larger leaf volume and stem diameter than the plants obtained from the shoots incubated in the laboratory. 


\section{Resumen}

J.R. Enríquez-del Valle, K.H. Antonio-Luis, G. Rodríguez-Ortiz y G.V. Campos-Ángeles. 2016. Efecto del medio de cultivo y la incubación en las características de plantas de agave micropropagadas. Cien. Inv. Agr. 43(2):263-272. Se obtuvieron brotes adventicios de Agave potatorum Zucc a partir de tejidos de tallo y éstos se enraizaron en diferentes medios de cultivo gelificados, con pH 5.8, que contenían: 1) sales minerales MS (Murashige and Skoog) en concentraciones diferentes (50, 75, 100\%); 2) ácido indol-3-butírico (AIB) en cantidades diferentes $\left(0 ; 0,5 ; 1 \mathrm{mg} \mathrm{L}^{-1}\right)$. El total de brotes en cada medio de cultivo se separó en dos grupos para incubarlos durante 84 días en condiciones diferentes: laboratorio o invernadero. Resultaron 18 tratamientos, en un experimento completamente al azar con arreglo factorial $3 \times 3 \times 2$. Las raíces tardaron en emerger entre 10 a 14 días según la condición de cultivo. A los 28 días de incubar los brotes en los tratamientos: medio con $75 \%$ sales inorgánicas, $0.5 \mathrm{mg} \mathrm{L}^{-1} \mathrm{AIB}$; medio de cultivo con 50\% sales inorgánicas, $1 \mathrm{mg} \mathrm{L}^{-1} \mathrm{AIB}$, el 66,6 y 93,6\% de brotes habían formado raíces y a los 40 días de incubación todos los brotes tenían raíces. Transcurridos 84 días de incubación, los brotes de Agave en medios de cultivo con $1 \mathrm{mg} \mathrm{L}^{-1}$ de AIB originaron plantas más grandes en ancho de hojas, diámetro del tallo, área de la sección transversal de la hoja en su parte basal; pero similar cantidad de raíces que plantas obtenidas en medios sin AIB. Al incrementar la concentración de sales inorgánicas en el medio de cultivo, se obtuvieron plantas más grandes. Las plantas micropropagadas obtenidas en invernadero o laboratorio tuvieron sus hojas de 8,9 y $5,4 \mathrm{~cm}$ de longitud, 1,8 y $0,8 \mathrm{~cm}^{3}$ de volumen foliar, el tallo de 1,8 y $0,5 \mathrm{~cm}$ de diámetro, 6,6 y 5,2 raíces, respectivamente.

Palabras clave: ácido indol-3-butírico, ambiente de incubación, iluminación fluorescente, radiación solar, sales minerales.

\section{References}

Abreu, E., G. González, R. Ortiz, P. Rodríguez, R. Domech, and M. Garriga. 2007. Evaluación de vitroplantas de henequén (Agave fourcroydes Lem) durante la fase de aclimatización. Cultivos Tropicales 28:5-11.

Aguirre-Dugua, X., and L.E. Eguiarte. 2013. Genetic diversity, conservation and sustainable use of wild Agave cupreata and Agave potatorum extracted for mezcal production in Mexico. Journal of Arid Environments 90:36-44.

Aragón C.E., M. Escalona, I. Capote, D. Pina, I. Cejas, R. Rodríguez, M.J. Cañal, J. Sandoval, S. Roels, P. Debergh and J. Gonzalez-Olmedo. 2005. Photosynthesis and carbon metabolism in plantain (Musa AAB) plantlets growing in temporary inmersion bioreactors and during ex vitro acclimatization. In vitro Cell. Dev. Biol.-Plant 11: 550-554.

Bautista-Justo, M., L. García-Oropeza, J.E. BarbozaCorona, and L.A. Parra-Negrete. 2001. El Agave tequilana Weber y la producción de tequila. Acta Universitaria 11:26-34.

Baskaran, P., and J. Van-Staden. 2013. Rapid in vitro propagation of Agapanthus praecox. South African Journal of Botany 86:46-50.

Blanco, M., and R. Valverde. 2004. Micropropagación de Philodendro sp. Agronomía Costarricense 28:39-46.

Castellanos, H.O.A., S.A. Rodríguez, D.J.M Rodríguez, and G.B. Rodríguez. 2006. Organogénesis indirecta y enraizamiento in vitro de Paulownia elongata. e-Gnosis 4:1-12.

Cui, Y., E. Hahn, T. Kozai, and K. Paek. 2000. Number of air exchanges, sucrose concentration. Photosynthetic photon flux, and differences in photoperiod and dark period temperatures affect growth of Rehmannia glutinosa plantlets in vitro. Plant Cell, Tissue and Organ Culture 62:219-226.

Debergh, P.C., and P.E. Read. 1991. Micropropagation. In: Debergh, P.C., and R.H. Zimmerman 
(eds.). Micropropagation Technology and Application. p. 1-13.

Domínguez, R.M.S., J.M.L. González, G.C. Rosales, V.C. Quilloñes, D.L.S. Delgadillo, O.J. Mireles, and M.B.E Pérez. 2008. El cultivo in vitro como herramienta para el aprovechamiento, mejoramiento y conservación de especies del género Agave. Investigación y Ciencia de la Universidad Autónoma de Aguascalientes 16:53-62.

Domínguez-Torrejón, G, and M.L. Donayre-Gómez. 2006. Aclimatación de Uncaria tormentosa (Willd.) DC. Producida in vitro. Ecología Aplicada 5:67-74.

Enríquez-del Valle, J.R. 2008. La propagación y crecimiento de agaves. Fundación Produce Oaxaca AC-Instituto Tecnológico del Valle de Oaxaca. México. 46 pp.

Enríquez-del Valle, J.R., G. Carrillo-Castañeda, and J. Rodríguez de la O. 2005. Sales inorgánicas y ácido indolbutírico en el enraizamiento in vitro de brotes de Agave angustifolia. Rev. Fitotec. Mex. 28:175-178.

Escamilla-Treviño, L.L. 2012. Potential of plants from the genus Agave as bioenergy crops. Bioenergy Research 5:1-9.

Fondom, N.Y., S. Castro-Nava, and A.J. Huerta. 2009. Photoprotective mechanisms during leaf ontogeny: cuticular development and anthocyanin deposition in two morphs of Agave striata that differ in leaf coloration. Botany 87:1186-1197.

Garrido, G., J.R. Guerrero, E.A. Cano, M. Acosta, and J. Sánchez-Bravo. 2002. Origin and basipetal transport of the AIA responsible for rooting of carnation cuttings. Physiol. Plant. 114: 303-312.

González, M., N. Mogollón, G. Alvarado, A. Giménez, and T. Capote. 2012. Efecto del medio de cultivo in vitro y la fuente nitrogenada sobre el crecimiento del cocuy (Agave cocui Trelease). Bioagro 24:39-44.

Kitaya, Y., O. Fukuda, T. Kosai, and C. Kirdmanee. 1995. Effects of lighting intensity and lighting direction on the photoautotrophic growth and morphology of potato plantlets in vitro. Scientia Horticulturae 62:15-24.

Madrigal, L.R., F.E. Pineda, and J.L. Rodríguez de la O. 1990. Agave. In: Ammirato P.V., D.A. Evans,
W.R. Sharp, and Y.P.S. Bajaj (eds.). Handbook of Plant Cell Culture 5:206-227.

Miguel-Luna, M.E., J.R. Enríquez-del Valle, V.A. Velasco-Velasco, Y. Villegas-Aparicio, J.C. Carrillo-Rodríguez, and G. Rodríguez-Ortiz. 2013. Composición del medio de cultivo y la incubación para enraizar brotes de Agave. Revista Mexicana de Ciencias Agrícolas 6:1151-1159.

Murashige, T., and F Skoog. 1962. A revised medium for rapid growth and bioassays with tobacco tissue cultures. Physiol. Plant. 15:473-497.

Negi, D., and A. Saxena. 2011. Micropropagation of Bambusa balcooa Roxb. Through axillary shoot proliferation. In Vitro Cell.Dev.Biol.-Plant 47: 604-610.

Pérez, M., E. Balch, A.M.J. Esparza, and R.M.E. Pérez. 2012. Conservación in vitro de germoplasma de Agave spp. bajo condiciones de crecimiento retardado. Rev. Fitotec. Mex. 35:279287.

Pospíšilová, J., D. Haisel, H. Synková, J. Čatský, N. Wilhelmová, Š. Plzáková, D. Procházková, and F. Šrámek. 2000. Photosynthetic pigments and gas exchange during ex vitro acclimation of tobacco plants as affected by $\mathrm{CO}_{2}$ supply and abscisic acid. Plant Cell, Tissue and Organ Culture 61:125-133.

Sánchez-Urbina, A., L.M.C. Ventura-Canseco, T. Ayora-Talavera, M. Abud-Archila, M.A. PérezFarrera, L. Dendooven, and F.A. GutiérrezMiceli. 2008. Seed germination and in vitro propagation of Agave grijalvensis an endemic endangered Mexican species. Asian Journal of Plant Sciences 7:752-756.

Scaranari, C., L.P.A. Martins, and P. Mazzafera. 2009. Shading and periods of acclimatization of micropropagated banana plantlets cv. Grande Naine. Sci Agric. 66:331-337.

Teixeira, da S.J.A., D.T.G. Dam, and M. Tanaka. 2005. In vitro acclimatization of banana and Cymbidium. International Journal of Botany 1:41-49.

Zhang, Y-M., X. Li, Z. Chen, J.-F. Li, J.-Y. Lu, and W.Z. Zhou. 2013. Shoot organogenesis and plant regeneration in Agave hybrid, No. 11648. Scientia Horticulturae 161: 30-34. 